Article

\title{
Exploring Avoided Environmental Impacts as Well as Energy and Resource Recovery from Microbial Desalination Cell Treatment of Brine
}

\author{
Rosa Anna Nastro ${ }^{1}\left(\mathbb{D}\right.$, Enrica Leccisi ${ }^{1, *}$, Maria Toscanesi $^{2}(\mathbb{D})$, Gengyuan Liu ${ }^{3}\left(\mathbb{D}\right.$, Marco Trifuoggi $^{2}(\mathbb{D})$ \\ and Sergio Ulgiati $1,3, *$ (D)
}

1 Department of Science and Technology, Parthenope University of Naples, 80143 Naples, Italy; r.nastro@uniparthenope.it

2 Department of Chemical Sciences, University of Naples Federico II, 80126 Naples, Italy; maria.toscanesi@unina.it (M.T.); marco.trifuoggi@unina.it (M.T.)

3 State Key Joint Laboratory of Environment Simulation and Pollution Control, School of Environment, Beijing Normal University, Beijing 100875, China; liugengyuan@bnu.edu.cn

* Correspondence: enrica.leccisi@uniparthenope.it (E.L.); sergio.ulgiati@uniparthenope.it (S.U.)

Citation: Nastro, R.A.; Leccisi, E.; Toscanesi, M.; Liu, G.; Trifuoggi, M.; Ulgiati, S. Exploring Avoided Environmental Impacts as Well as Energy and Resource Recovery from Microbial Desalination Cell Treatment of Brine. Energies 2021, 14, 4453. https://doi.org/10.3390/en14154453

Academic Editor: Iqbal M. Mujtaba

Received: 21 May 2021

Accepted: 13 July 2021

Published: 23 July 2021

Publisher's Note: MDPI stays neutral with regard to jurisdictional claims in published maps and institutional affiliations.

Copyright: (c) 2021 by the authors. Licensee MDPI, Basel, Switzerland. This article is an open access article distributed under the terms and conditions of the Creative Commons Attribution (CC BY) license (https:// creativecommons.org/licenses/by/ $4.0 /)$.

\begin{abstract}
Seawater represents a potential resource to ensure sustainable availability of water for population and irrigation purposes, especially in some areas of the world. Desalination processes allow the production of fresh water, but they generate also brine as waste product. Sustainable brine management should be identified to ensure proper disposal and potentially resource recovery. This experimental study showed that emerging technologies such as Microbial Desalination Cells (MDCs) may provide a valuable contribution to the sustainability of the seawater desalination sector. In this paper, we report results on lab-scale desalination brine treatments applying MDCs, which allow energy savings, resource recovery, environmental impact minimization, and reduction of the organic load in municipal wastewater. Our results showed that MDCs' treatment allows the removal of approximately $33 \mathrm{~g}$ of salts (62\% of the total) - including chlorides, bromides, and sulphatesfrom $20 \mathrm{~mL}$ of brine within $96 \mathrm{~h}$. The MDCs, according to the source of energy and the presence of mature biofilm at the anode, spent 7.2 J, 7.9 J, and $9.6 \mathrm{~J}$ in the desalination process, with the higher amount of energy required by the abiotic system and the lesser by the MDCs fed with just wastewater. Our approach also showed environmental and energy reductions because of potential metal recovery instead of returning them into marine environment. We quantified the avoided life cycle of human and marine eco-toxicity impacts as well as the reduction of cumulative energy demand of recovered metals. The main benefit in terms of avoided toxicity would arise from the mercury and copper recovery, while potential economic advantages would derive from the recovered cobalt that represents a strategic resource for many products such as battery storage systems.
\end{abstract}

Keywords: brine treatment; wastewater treatment; metals; resource recovery; energy reduction; life-cycle analysis

\section{Introduction \\ 1.1. Brine Production}

Brine is the hypersaline concentrate produced as the main by-product of a seawater desalination process, which is a viable option for freshwater recovery, removing salts, and meeting the quality requirements for human uses [1,2].

However, brine production from desalination represents a critical environmental issue because of residual organic chemicals and heavy metals (such as copper, nickel, iron, chromium, zinc), high salinity, and relatively high temperature [3-5], which affect water ecosystems, soil, and groundwater [6]. The potential damages to the environment include eutrophication, $\mathrm{pH}$ fluctuations, and heavy metals and chemicals discharge in 
marine environments [4-7]. Recent estimates showed that for each $\mathrm{m}^{3}$ of freshwater water produced, approximately $1 \frac{1}{2} \mathrm{~m}^{3}$ of brine may be discharged [2]. Globally, desalinated water production is estimated to be 95.4 million $\mathrm{m}^{3}$ /day, while associated generation of brine is 141.5 million $\mathrm{m}^{3} /$ day [2].

Usually, brine is discharged in seawater and water bodies, applied on land, injected into deep wells, or treated in evaporation ponds, with environmental consequences for marine and soil ecosystems and then, indirectly, for human health [1,2,8]. Considering the significant impacts that brine disposal can generate and the increasing number of desalination plants worldwide, technological and research efforts are needed to address this challenge $[5,6,9]$. One of the main approaches investigated is the brine prevention leading to the setup of Zero Liquid Discharge (ZLD) systems [10], based on brine thermal treatment [11]. Other technologies for brine treatment are membrane-based processes such as reverse osmosis and thermal-based technologies such as brine concentrator and crystallizer [8]. All the listed processes require a certain amount of energy and, thus, they contribute to the greenhouse gases' (GHGs') emissions [6]. Different approaches have been applied with the aim of improving desalination processes' sustainability, such as the utilization of renewable energies and waste heat, the use of high-quality materials, and proper maintenance plans [6,8]. In comparison to cost- and energy-intensive current water desalination technologies such as thermal and membrane-based desalination processes, MDCs can take advantage of microbial catalysis to produce bioenergy from wastewater (or other substrates able to sustain microbial growth) to drive the desalination process. thus reducing, or even avoiding, the use of energy from other sources (first and foremost, fossil fuels). As a result, MDCs not only are able to perform a significant reduction of salts' content in salty waters, but also remediate wastewater by decreasing the organic load and nitrogen and phosphorous compounds' concentration. Recently, researchers from different parts of the world set up MDCs with four or more chambers able to produce molecules such as hydrogen, ammonia, sulphate, and volatile fatty acid [12,13]. The last, but not the least, the possibility to develop a bio-desalination process by using membranes of cyanobacteria, has been demonstrated in MDCs, at least as a proof of concept [12]. For all the abovementioned reasons, MDCs can develop as an energy- and cost-effective and environmentally sustainable technology for saline water desalination [12,13].

\subsection{Microbial Desalination Cells (MDCs): An Emerging Technology}

Bio-electrochemical Systems (BESs) represent an emerging technology-that may be scaled up at the industrial level-useful for many sectors. Among them, the main applications are to wastewater treatment, production of bioenergy from biomass, sediment/soil remediation, biosynthesis of commodity chemicals, and the setup of biomedical devices [14-19]. Recently, an innovative process, able to combine wastewater treatment and salty waters' desalination, captured the interest of the scientific community, the Microbial Desalination Cells (MDCs). MDCs are based on the metabolism of electroactive bacteria, which provide the energy needed to drive the desalination process $[15,20,21]$. Sources of energy (namely, the feedstock provided to bacteria) can be wastewater, activated sludge, dyed industrial effluents, cattle manure, nitrates in groundwater, and many others even though, especially at lab scale, sodium acetate is provided as a source of carbon and energy [22,23]. As essentially based on microbial metabolism, MDCs are listed among the renewable energy-based technologies, even though they can be in need for external potentials to control the desalination process itself $[15,22]$. Recently, some authors reported the recovery of value-added products (such as $\mathrm{H} 2, \mathrm{HCl}$, fulvic and humic acids, volatile fatty acids, $\mathrm{SO}_{4}{ }^{2-}$ ) and the removal of pollutants from wastewater in association with the desalination process in four- or even five-chambers MDCs [22,24]. Other applications explored are groundwater remediation and hardness removal in water [23]. MDCs are interesting also because of their behavior as supercapacitors [25]. Santoro et al. [21] showed the increase of power outputs (up to $3.01 \pm 0.01 \mathrm{~W} \mathrm{~m}^{-2}$ ) and desalination efficiency (about $60 \%$ removal in $44 \mathrm{~h}$ ) in comparison with their negative control (traditional MDCs) by 
connecting a third electrode to the cathode and applying a pulse current of 2 and $3 \mathrm{~mA}$ every $2 \mathrm{~s}$. Briefly, model MDCs are generally made up by three chambers (anode, cathode, and central chambers) separated by ions- exchanging membranes, even though multiplechambers systems are used for the recovery of chemicals [15,23]. Figure 1 shows the schematic diagram of three- and four-chambers MDCs, according to Rahman et al. [22].
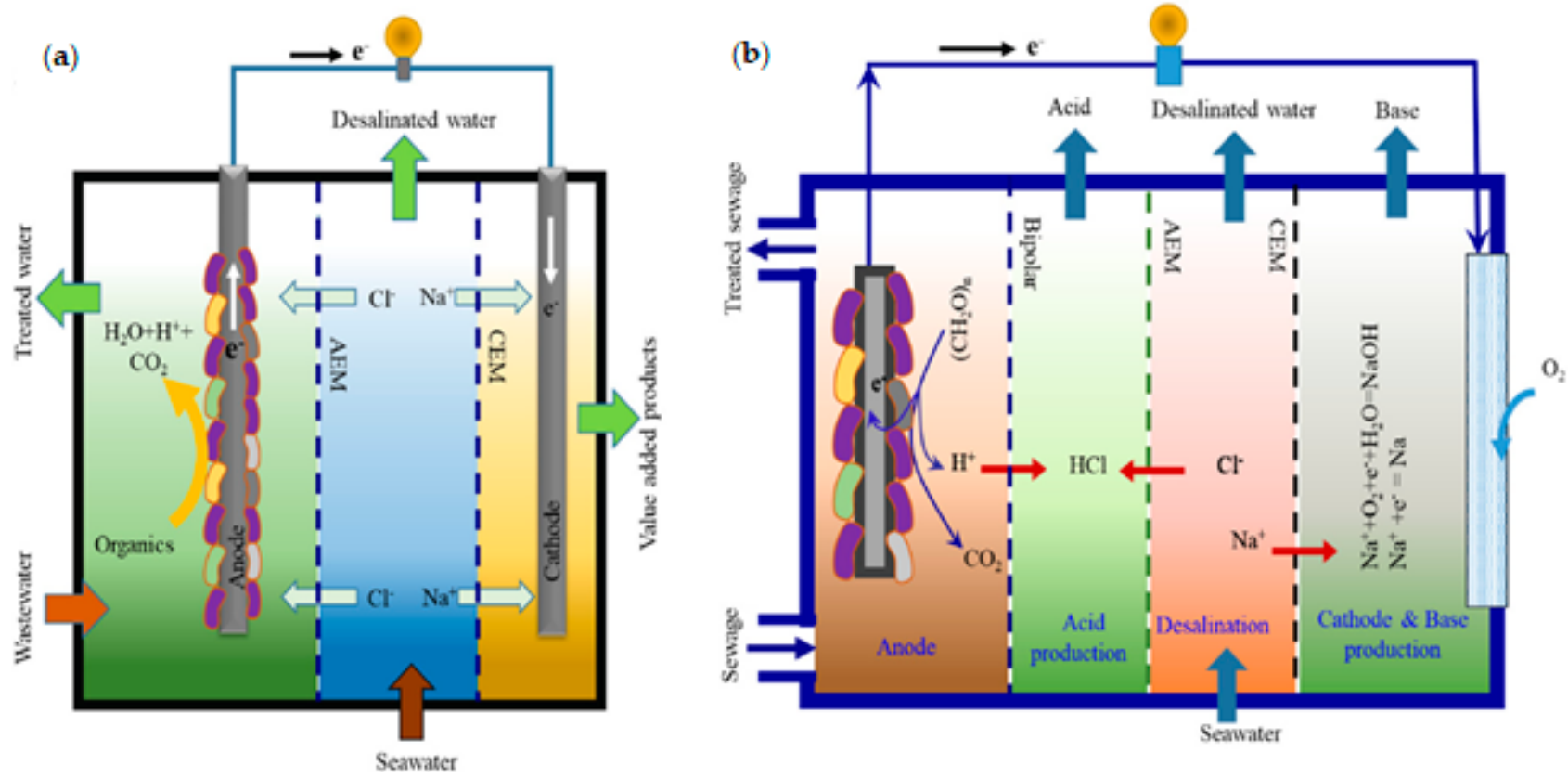

Figure 1. In (a), a three-chambers MDCs for salty water desalination is sketched. In (b), the layout of more recent MDCs with four-chambers, able to realize the synthesis of $\mathrm{HCl}$ in addition to desalination, is displayed. In all MDCs, ion-exchanging membranes realize the separation between compartments. AEM: anionic-exchanging membrane; CEM: cationic-exchanging membrane (with permission of Rahman et al., 2021) [22].

Even though much progress has been achieved in recent years, some bottlenecks have to be overcome in order to realize scalable applications of MDCs such as membrane fouling, high internal resistance and electric outputs, and $\mathrm{pH}$ fluctuations [23,26].

\subsection{Goals of the Paper}

With the aim of providing sustainable brine management options, in this work we explored the application of MDCs as brine treatment and, as a benefit of metal recovery, we evaluated the avoided human toxicity impacts by applying Life Cycle Analysis (LCA). The main research outcomes are MDCs can act as a stand-alone, energy self-sufficient solution for brine treatment removal of salt content in brine and organic load from a mix of municipal wastewater and mineral medium; potential recovery of metals contained in brine; and minimization of the life cycle of human and eco-toxicity impacts, as well as reduction of cumulative energy demand associated with the recovered metals.

\section{Materials and Methods}

\subsection{MDCs' Setup}

Three-chamber MDCs were assembled using acrylic bodies, screws, rubber gaskets, and carbon cloth material purchased at the University of Reading (UK). We filled the anodic, central, and cathodic chambers with $20 \mathrm{~mL}$ of anolyte, brine, and catholyte, respectively. A detailed description of the liquid media is reported in Section 2.2.

We used Fumasep ${ }^{\circledR}$ FAS-50 and Fumasep ${ }^{\circledR}$ FKM (Fumatech Inc., Sankt Ingbert, Germany) as anion- and as cation-exchanging membranes. Before being used, the membranes were soaked in a $0.5 \mathrm{M} \mathrm{NaCl}$ solution for $24 \mathrm{~h}$, according to manufacturer's instructions. Synthetic tissues were applied at the interface between membranes and liquids, to limit 
membranes fouling. Both anode and cathode electrodes were crafted using carbon cloth pieces of $6 \mathrm{~cm} \times 4 \mathrm{~cm}$, folded to form a double layer with overall surface of $52 \mathrm{~cm}^{2}$, and fixed with a titanium wire of $0.5 \mathrm{~mm}$ in diameter, which acted also as an electrons' collector at the anode. All catholytes were constantly aerated by an air pump. As to microbial inocula, we incubated the anodes of MDC_2 and MDC_3 in $300 \mathrm{~mL}$ of activated sludgepreviously sampled at a wastewater treatment plant in Naples District-for 1 month at $20 \pm 2{ }^{\circ} \mathrm{C}$. In order to foster the formation of anodic mature electroactive biofilms, we applied a potential of $+550 \mathrm{mV}$ vs. $\mathrm{Ag} / \mathrm{AgCl}$ reference electrode for 2 weeks, with the aim to reduce MDC_2 and MDC_3 start-up phase [19].

Then, we set up and evaluated the performance of MDCs (1) with (MDC_2 and MDC_3) and without (MDC_cntr) mature biofilm at the anode, and (2) with (MDC_3 and MDC_cntr) and without (MDC_2) the application of + $1.5 \mathrm{~V}$ external voltage at the electrodes, as reported in Figure 2. For evaluating MDCs' performance, we calculated the following parameters: current density (CD), power density (PD), columbic efficiency (CE), and polarization behavior $[16,19,23]$. CD and PD referred to the cathode surface. In addition, in MDC_2 (mature anode biofilm, closed-circuit operation), we estimated the amount of energy (expressed in Joule) produced by the chemical energy stored in the fuel, which drove the desalination process.
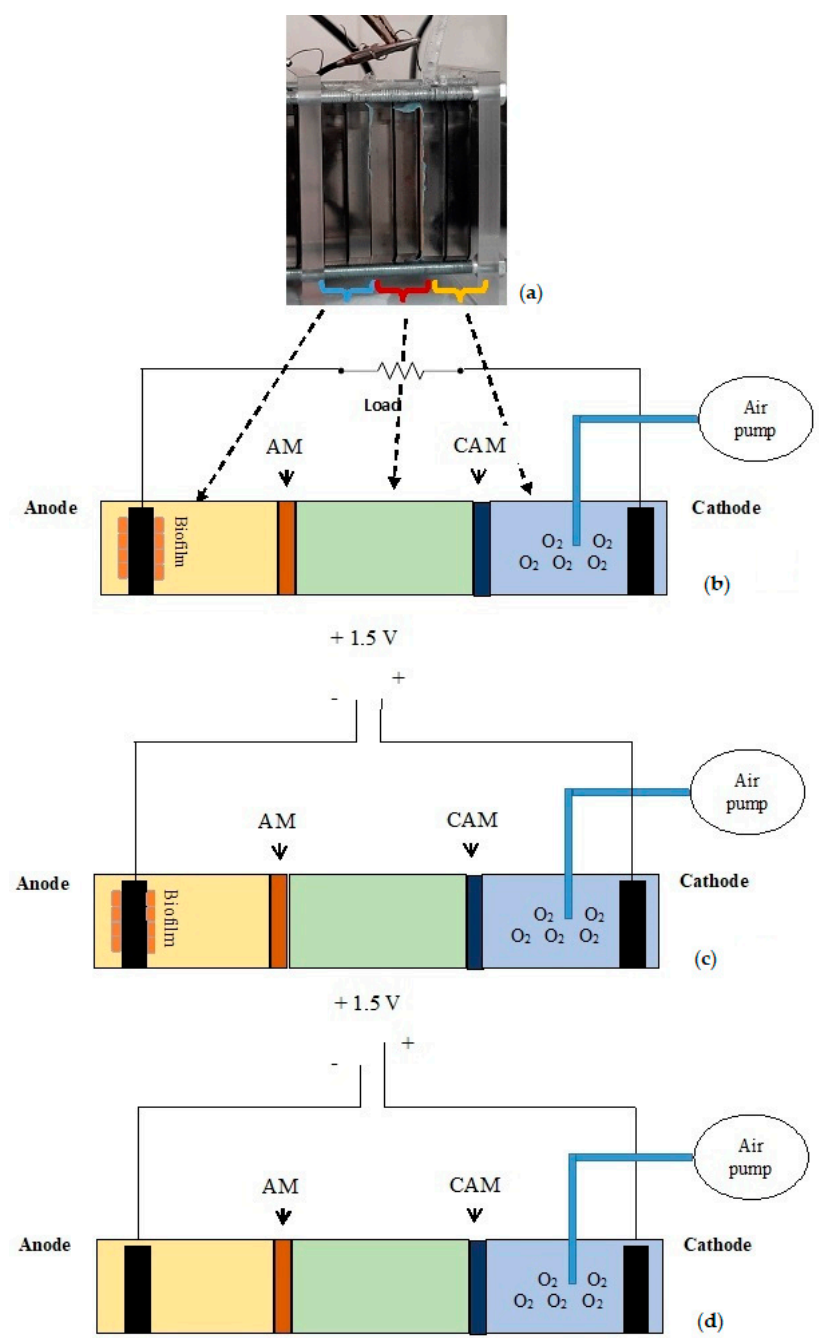

Figure 2. MDCs' experimental scheme. (a) Image of lab-scale MDCs; (b) MDC with mature biofilm, no external source of potential connected; (c) MDC with mature biofilm, 1.5-V external voltage applied; (d) MDC with no microbial inoculum (negative control). AM: anions-exchanging membrane; CAM: cations-exchanging membrane; Load: external load. 


\subsection{Liquid Media}

MDCs were applied to treat the brine produced by a desalination plant in Italy (Sicily Region). The collected brine was stored at $4{ }^{\circ} \mathrm{C}$ and then added to the central chamber of MDCs $(20 \mathrm{~mL})$. We used as anolyte a mixture of wastewater and mineral salt medium (GM Medium) in a 1:1 ratio. Wastewater samples were collected at the sewage treatment plant of Marcianise, in Naples District. As to GM Medium, it was prepared according to Logan et al. [26] by adding $4.09 \mathrm{~g} \mathrm{Na}_{2} \mathrm{HPO}_{4}, 2.93 \mathrm{~g} \mathrm{NaH}_{2} \mathrm{PO}_{4} \times \mathrm{H}_{2} \mathrm{O}, 0.31 \mathrm{~g} \mathrm{NH}_{4} \mathrm{Cl}$, $0.13 \mathrm{~g} \mathrm{KCl}, 12.5 \mathrm{~mL}$ metal salts solution, and $5 \mathrm{~mL}$ vitamin solution to one liter of distilled water. Sodium acetate $(2 \mathrm{~g} / \mathrm{L})$ was used as an additional source of carbon and energy in GM Medium, with a final concentration in the fuel of $0.01 \mathrm{M}$. A 100-mM PBS solution (pH 7.4, Applichem, Darmstadt, Germany) was used as catholyte. The latter was constantly aerated by means of an air pump. All experiments were performed in triplicate.

\subsection{DMCs' Operational Conditions}

Unlike MDC_2 and MDC_3, MDC_cntr was not inoculated with an anode previously colonized by bacteria in order to evaluate essentially the contribution of the $1.5-\mathrm{V}$ external potential on the desalination process. Immediately, the MDCs were left in Open Circuit Voltage (OCV) for 2 hours before performing a first polarization experiment, which was carried out using MBED NXP LPC1768 microcontroller and GNU OCTAVE 5.1.0 software. Then, MDC_2s were connected to an external resistor of $47 \Omega$ for the first $24 \mathrm{~h}$, then to $120 \Omega$ for a further $48 \mathrm{~h}$ and, finally, to $220 \Omega$ for about $24 \mathrm{~h}$. MDC_3 and MDC_cntr were connected to a 1.5-V battery following the same time schedule of MDC_2s (Figure 1). The applied voltage range was $1.5 \pm 0.1 \mathrm{~V}$. Once disconnected, respectively, from the loads and the batteries, all MDCs were left in OCV until they achieved a stable voltage. Then, we performed a new polarization experiment. Voltacraft DL191V dataloggers were used to record V values of all MDCs. Columbic Efficiency (EC) was calculated according to Nastro et al., 2014 [14]. The energy produced by MDC_2 and used to drive the desalination process was expressed, as usual, in J. After $96 \mathrm{~h}$ of operation at $20 \pm 2{ }^{\circ} \mathrm{C}$, we sampled brine, anolyte, catholyte, and membranes for chemical analyses. We also investigated the microbial populations at the anode of MDC_2 and MDC_3, using a Next Generation Sequencing method (ILLUMINA) to screen the rRNA 16S of both Proteo- and Archeobacteria in biofilms.

\subsection{Chemical Analyses}

We collected brine from MDC_2, MDC_3, and MDC_cntr replicates, obtaining a single sample of average composition for each system. In order to evaluate the recovery of metals and other ions, membranes from MDCs and negative controls were collected and stored in distilled water to avoid drying. Then, cation-exchange membranes were soaked in $3 \% \mathrm{v} / \mathrm{v}$ $\mathrm{HNO} 3$ solution to dissolve the absorbed cations. The obtained elutriates were analyzed for their content in $\mathrm{Al}, \mathrm{Cd}, \mathrm{Cr}, \mathrm{Fe}, \mathrm{Mn}, \mathrm{Hg}, \mathrm{Ni}, \mathrm{Pb}, \mathrm{Cu}$, and $\mathrm{Sb}$ by inductively coupled plasma with mass spectrometry (Aurora M90, Bruker Daltonics, Bremen, Germany). The anion membranes were soaked in a solution of $3.6 \mathrm{mM} \mathrm{Na} 2 \mathrm{CO} 3$ solution. The determination of chloride and sulphate was performed by ionic exchange chromatography with conductivity detector (IC 856, Metrohm, Herisau, Switzerland). With the aim of evaluating the desalination process efficiency, we analyzed treated brine for its $\mathrm{Na}^{+}, \mathrm{Cl}^{-}, \mathrm{Br}^{-}, \mathrm{K}^{+}, \mathrm{Mg}^{2+}$, $\mathrm{SO}_{4}{ }^{2-}$, and $\mathrm{Ca}^{2+}$ concentration after MDCs' treatment. The concentration of all anions and cations was measured by ionic exchange chromatography, coupled with a conductivity detector. Cations were separated by a Metrosep C4 250/4.0 column using $3.0 \mathrm{mM} \mathrm{HNO}_{3}$ as eluent and a flow rate of $0.9 \mathrm{~mL} / \mathrm{min}$, whereas anions were separated by a Metrosep A supp7 250/40 column using $3.6 \mathrm{mM} \mathrm{Na} 2 \mathrm{CO} 3$ as eluent at a flow rate of $0.7 \mathrm{~mL} / \mathrm{min}$. (IC 856, Metrohm, Herisau, Switzerland). The $\mathrm{pH}$ was measured by potentiometric methods (Mod 856/867, Metrohm, Herisau, Switzerland). Chemical Oxygen Demand (COD) in the anolytes was determined by oxidative acid digestion, followed by colorimetric measure 
(Hach, DR 3900, Düsseldorf, Germany). We carried out a $X^{2}$ Test $(\alpha=0.05)$ to analyze the results obtained by the three layouts.

\subsection{MDCs' Energy Inputs}

The amount of current intensity provided by the external batteries to MDC_3 and MDC_cntr was calculated according to the Kirchhoff's law:

$$
I_{b}=\left(V_{b}-O C V_{M D C}\right) / R_{M D C}
$$

where $I_{b}$ is the current intensity provided by the battery $\mathrm{b}$ and OCVMDC is the Open Circuit Voltage of MDCs (MDC_3 and MDC_cntr). RMDC is the internal resistance of MDCs. The overall power provided to MDCs' systems was calculated as follows:

$$
P_{b}=V_{b} * I_{b}=V_{b} *\left[\left(V_{b}-O C V_{M D C}\right) / R_{M D C}\right]
$$

where $P_{b}$ and $V_{b}$ are, respectively, the electric power and the voltage provided by the batteries, $I_{b}$ is the current intensity flowing through the systems, and OCVMDC and RMDC are as above. Starting from $P_{b}$ values, we calculated the overall energy amount provided to the systems for the entire duration of the experiments, expressed in J.

Further, we estimated the energy spent by the MDCs to remove from brine the metals captured by membranes ( $\mathrm{Al}, \mathrm{Cd}, \mathrm{Cr}, \mathrm{Fe}, \mathrm{Mn}, \mathrm{Hg}, \mathrm{Ni}, \mathrm{Pb}, \mathrm{Cu}, \mathrm{Sb}$ ). Using Faraday's law for electrochemical solutions and assuming as negligible the resistance of the brine to ions' migration, we calculated the electrical equivalent $E_{i}$ of each metal and the corresponding electric charge carried by each metal by means of Equations (3) and (4):

$$
\begin{aligned}
& E_{i}=\left(n_{i} / z_{i}\right) \\
& Q_{i}=E_{i} * F
\end{aligned}
$$

where $Q i$ is the electric charge carried by a specific ion and expressed in Coulomb, $F$ is the Faraday constant $\left(96,500 \mathrm{C} \mathrm{mol}^{-1}\right)$, and $n_{i}$ is the amount and $z_{i}$ is the charge of each considered metal. Then, we obtained the current (in Ampere) produced by the ions, according to Equation (5):

$$
I=Q_{i} / t
$$

where $t$ is the operation time, expressed in seconds. The power $(\mathrm{P})$ used by the system to move and separate metals from brine was calculated according to Ohm's law. Then, we calculated the amount of energy (expressed in Joule) needed to move and sequestrate metals from brine as:

$$
E=P * t
$$

We reported, then, the energy values in $\mathrm{MJ} / \mathrm{m}^{3}$ of treated brine.

\subsection{Life Cycle Analysis (LCA)}

Life Cycle Analysis (LCA) is an analytical methodology that is considered to be the most comprehensive approach for the evaluation of potential environmental impacts of a system, service, or product, through its entire life cycle $[27,28]$. LCA allows the quantification of all energy and material inputs, outputs, and emissions, in each stage of a product's life cycle from the extraction of raw materials to the component and product manufacturing, transport, distribution, operation phase, maintenance, reuse, recycling, and disposal. It has been standardized by the Society of Environmental Toxicology and Chemistry (SETAC) and the International Organization for Standardization (ISO) Standards 14,040 and $14,044[29,30]$.

LCA allows the impact quantification from resource extraction, raw material production, manufacturing, refining, distribution, use and re-use, maintenance, and end of life [31,32]. Among all the impact categories, LCA allows the calculation of the total primary energy harvested from the environment in order to produce a given amount of 
end product (such as electricity), commonly named cumulative energy demand (CED). CED breakdowns provide useful details on the energy demand needed for the life cycle stages, including mining activities. Moreover, LCA estimates the human toxicity potential (HTP), which quantifies the potential harm of a unit of chemical released into the environment based on the inherent toxicity of a compound and its potential dose, and marine eco-toxicity potential (ETP), which refers to the impact on marine ecosystems as a result of toxic emissions to air, water, and soil.

The life cycle impact assessment method used in this analysis was ReCiPe Midpoint (H) that provides characterization factors (CFs) calculated with USES-LCA [33]. Specifically, CFs of human and marine eco-toxicity account for the environmental persistence (fate), accumulation in the human food chain (exposure), and toxicity (effect) of each chemical, assuming chemicals in brine are not recovered, being instead released to the marine environment. Due to potential uncertainties of fate, exposure, and effect of each substance, toxicity impacts should be intended as first estimates to be further investigated. Toxicity results calculated at the mid-point level are expressed using as reference unit " $\mathrm{kg} \mathrm{1,4-}$ dichlorobenzene equivalent" (kg 1,4-DBeq). In order to be as complete as possible, in this study ReCiPe Endpoint $(\mathrm{H})$ was also applied with the aim of calculating avoided toxic impacts expressed also in terms of disability-adjusted life years (DALY), which take into account the years lost due to premature death or reduced quality of life due to illness. This metric is a combination of years of life lost due to premature mortality and the years of life lost due to disability as result of disease or its consequences. Finally, we also calculated the avoided biodiversity loss in terms of species disappeared per year. Mid-point and End-point avoided impacts provide useful first indications for potentially avoided damage impacts, although, as mentioned above, it should also be considered that these metrics include high uncertainties due to complex dynamic interaction between chemicals, humans, and ecosystems as well as potential variations in the exposure time and different geographical criticalities. Regarding the data sources, the foreground life cycle inventory used in this study corresponded to the specific mass of each recovered metal, applying MDC_2 treatment to the produced brine, while the background life cycle inventory database was based on the Ecoinvent database version 3 [34]. As a practical standpoint, the analysis was performed using the SimaPro software version 9.

\section{Results and Discussion}

\subsection{Polarization Behavior and Energy Outputs}

MDC_2s and MDC_3s showed a proper polarization about $24 \mathrm{~h}$ after the setup, while no significant polarization behavior was observed in the abiotic control (MDC_cntr). Among all MDCs, MDC_2 revealed the highest energy production, with $8.97 \pm 4.2 \mathrm{~mA} / \mathrm{m}^{2}$ and $1.6 \pm 0.4 \mathrm{~mW} / \mathrm{m}^{2}$ average values over 12 different polarization experiments. Less stability and PD were observed in MDC_3, with $0.38 \pm 0.21 \mathrm{~mW} / \mathrm{m}^{2}$ and $8.83 \pm 6.7 \mathrm{~mA} / \mathrm{m}^{2}$ maximum values on average. These results showed that the application of the external voltage did not improve the performance of MDCs (as setup in this experiment) in terms of polarization and power outputs (Figure 3a,b). 


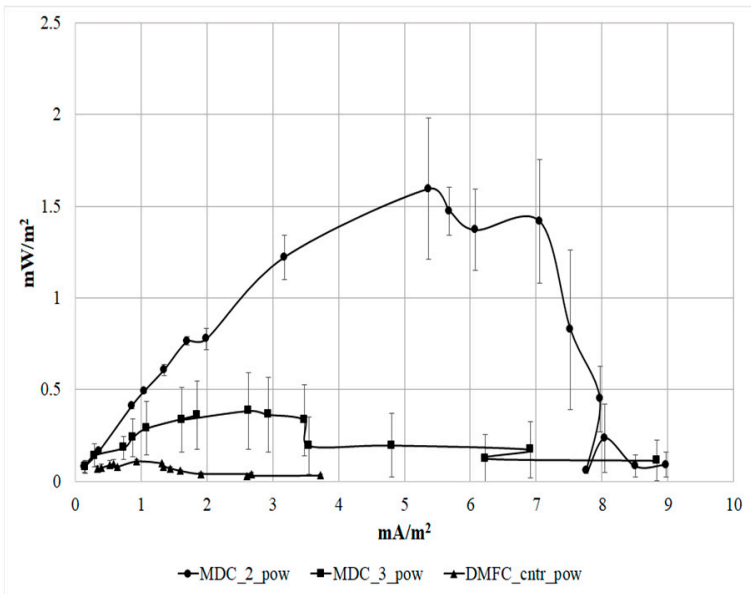

(a)

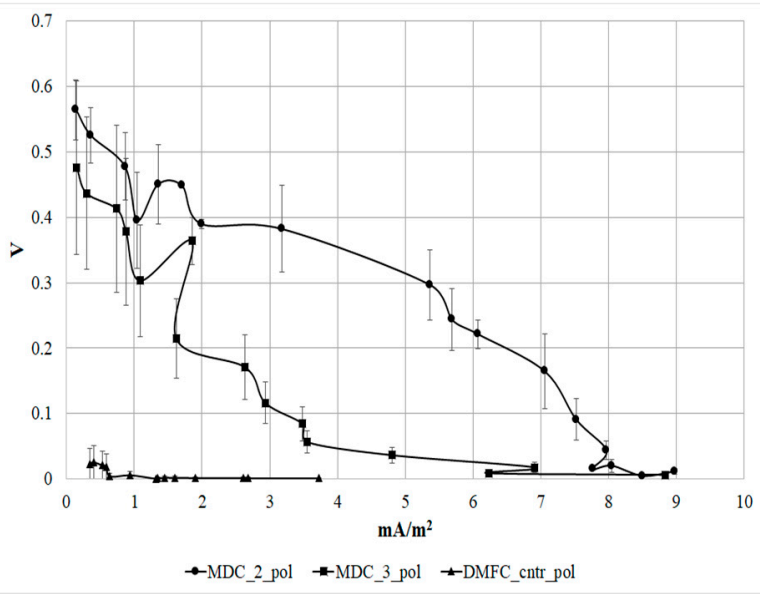

(b)

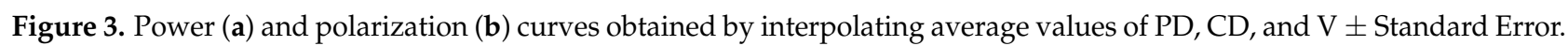

As expected, COD decreased significantly in MDC_2 anolyte: The residual amount (93 mg/L COD) was only $23 \%$ and $25 \%$ of COD in MDC_cntr (410 mg/L) and MDC_3 $(379 \mathrm{mg} / \mathrm{L})$, respectively. MDC_2 received by wastewater an approximate energy amount of $7.2 \mathrm{~J}$ to be spent in the desalination process (with a CE of 26.8\%). As to MDC_3 and MDC-cntr, the overall energy (Equation (2)) provided by the external batteries was $7.7 \mathrm{~J}$ and $9.6 \mathrm{~J}$, respectively. Further, the estimated energy provided by the wastewater in MDC_3 was $0.29 \mathrm{~J}$. The overall energy spent in the desalination process in MDC_3 was $7.9 \pm 0.1 \mathrm{~J}$. As to the energy needed to capture $\mathrm{Al}, \mathrm{Cd}, \mathrm{Cr}, \mathrm{Fe}, \mathrm{Mn}, \mathrm{Hg}, \mathrm{Ni}, \mathrm{Pb}, \mathrm{Cu}$, and $\mathrm{Sb}$ at the membranes, according to our estimation, MDC_2 required the smaller amount of energy $\left(3.24 \times 10^{-3} \mathrm{MJ} / \mathrm{m}^{3}\right)$ in comparison to MDC_cntr $\left(1.63 \times 10^{-2} \mathrm{MJ} / \mathrm{m}^{3}\right)$. MDC_3 required the highest amount of energy $\left(6.18 \times 10^{-1} \mathrm{MJ} / \mathrm{m}^{3}\right)$. This result could find a possible explanation in the increase in cationic membrane resistance due to the biological activity of bacteria at the membrane interface at anode compartment. Further studies may be needed to fully explain this result.

\subsection{Microbiological Analyses}

The analyses of microbial communities at the anodes revealed a prevalence of Pseudomonadaceae in MDC_2 (52.5\%), almost absent in MDC_3 (1.85\%). This result indicates that Pseudomonadaceae played an important role in the electrogenesys. In general, MDC_2 anodic community showed less diversity in comparison to MDC_3, in consequence of the different operational conditions realized (Table 1).

Table 1. Microbial taxa (families) in MDC_2 and MDC_3.

\begin{tabular}{llll}
\hline \multicolumn{1}{c}{ Taxa } & MDC_2 & MDC_3 \\
\hline Bacillales_Incertae Sedis XII & 0 & & 1.90 \\
Bifidobacteriaceae & 0.16 & 5.41 \\
Clostridiaceae 1 & 1.48 & 1.35 \\
Clostridiales_Incertae Sedis XI & 0.16 & 1.55 \\
Coriobacteriaceae & 0.00 & 1.35 \\
Incertae Sedis XI & 0.16 & 53.72 \\
Moraxellaceae & 30.87 & 2.53 \\
Parachlamydiaceae & 0 & 2.43 \\
Peptostreptococcaceae & 0.16 & 1.85 \\
Pseudomonadaceae & 52.55 & 1.07 \\
Unclassified_Acidimicrobiales & 0 & 1.73 \\
Unclassified_Actinomycetales & 0 &
\end{tabular}


Table 1. Cont

\begin{tabular}{llll}
\hline \multicolumn{1}{c}{ Taxa } & MDC_2 & & MDC_3 \\
\hline Unclassified_Alphaproteobacteria & 2.46 & & 0.48 \\
Unclassified_Gammaproteobacteria & 7.06 & & 3.02 \\
Xanthomonadaceae & 0 & 1.24 \\
Others $<1 \%$ & 4.93 & 18.99 \\
\hline
\end{tabular}

As to Archeobacteria, Methanobacteriaceae were prevalent in both MDC_2 (88.2\%) and MDC_3 (87.9\%), followed by Methanospirillaceae (5.9\% and 3.5\%) and an Unclassified_Euryarchaeota (5.9\% and 5.4\%). It is interesting to notice the presence (just in MDC_3) of a taxa including ammonia oxidizing bacteria, the Nitrososphaeraceae.

\subsection{Chemical Analyses}

In Table 2, we report the $\mathrm{pH}$ values and the concentration of the most abundant salts in brine before and after its treatment in MDCs. At the end of the treatment, we compared the residual dissolved salts' concentration of MDC_2 and MDC_3 with the MDC_cntr to investigate the advantage of electrogenesis (in two different operational conditions) in comparison with a similar chemical-physical treatment, in which an external voltage drives the desalination process.

Table 2. Main salts' content in brine before and after the treatment in MDCs.

\begin{tabular}{cccccc}
\hline \multirow{2}{*}{ Parameters } & $\begin{array}{c}\text { Units of } \\
\text { Measure }\end{array}$ & Brine & MDC_2 & MDC_3_ & MDC_cntr_ \\
\hline $\mathrm{pH}$ & & $6.7 \pm 0.2$ & $6.6 \pm 0.2$ & $6.8 \pm 0.2$ & $6.8 \pm 0.2$ \\
$\mathrm{Cl}$ & $\mathrm{mg} / \mathrm{L}$ & 228718 & 76771 & 80674 & 89636 \\
$\mathrm{Br}^{-}$ & $\mathrm{mg} / \mathrm{L}$ & 176 & 74.3 & 83 & 86.3 \\
$\mathrm{SO}_{4}^{-2}$ & $\mathrm{mg} / \mathrm{L}$ & 3937 & 1724 & 1521 & 1700 \\
$\mathrm{Na}^{+}$ & $\mathrm{mg} / \mathrm{L}$ & 149934 & 63681 & 55412 & 64921 \\
$\mathrm{~K}^{+}$ & $\mathrm{mg} / \mathrm{L}$ & 4120 & 188 & 108 & 122 \\
$\mathrm{Ca}^{2+}$ & $\mathrm{mg} / \mathrm{L}$ & 1853 & 1037 & 852 & 886 \\
$\mathrm{Mg}^{2+}$ & $\mathrm{mg} / \mathrm{L}$ & 191 & 165 & 100 & 96.7 \\
\hline
\end{tabular}

Overall, we measured a decrease in total salt concentration of $8.7 \%$ and $9.3 \%$ in MDC_2 and MDC_3, respectively, in comparison with MDC_cntr. Considering the salt decrease in rejected brine at the end of treatment, MDC_2, MDC_3, and MDC_cntr removed, respectively, $62.7 \%, 63.9 \%$, and $59 \%$. As for metals' recovery, cationic membranes of MDC_2s captured $\mathrm{Sb}, \mathrm{Co}, \mathrm{Cr}, \mathrm{Fe}, \mathrm{Mn}, \mathrm{Pb}$, and $\mathrm{Hg}$, with a higher rate in comparison to MDC_3s (Figure 4). Nevertheless, when only external voltage was applied (MDC_cntr) Co, $\mathrm{Pb}, \mathrm{Al}, \mathrm{Fe}$, and $\mathrm{Mn}$, were collected in higher amounts.

A simple statistical analysis by the $X^{2}$ Test revealed significant differences between the amount of metals recovered in MDC_2 and MDC_cntr $(p=0.0039)$. We found a similar result between MDC_3 and MDC_cntr values $(p=0.037)$, which indicates that in MDCs the application of the external voltage could be not the prevalent force working. The role that microbial activity seems to play in the desalination process, with particular regards to metals' sequestration, could prevail the application of an external voltage. $X^{2}$ Test performed among the data obtained by MDC_2 and MDC_3 revealed the existence of a weak dependence between the two groups of data $(p=0.51)$. Nevertheless, this is a preliminary test and further data are needed to confirm this result. 


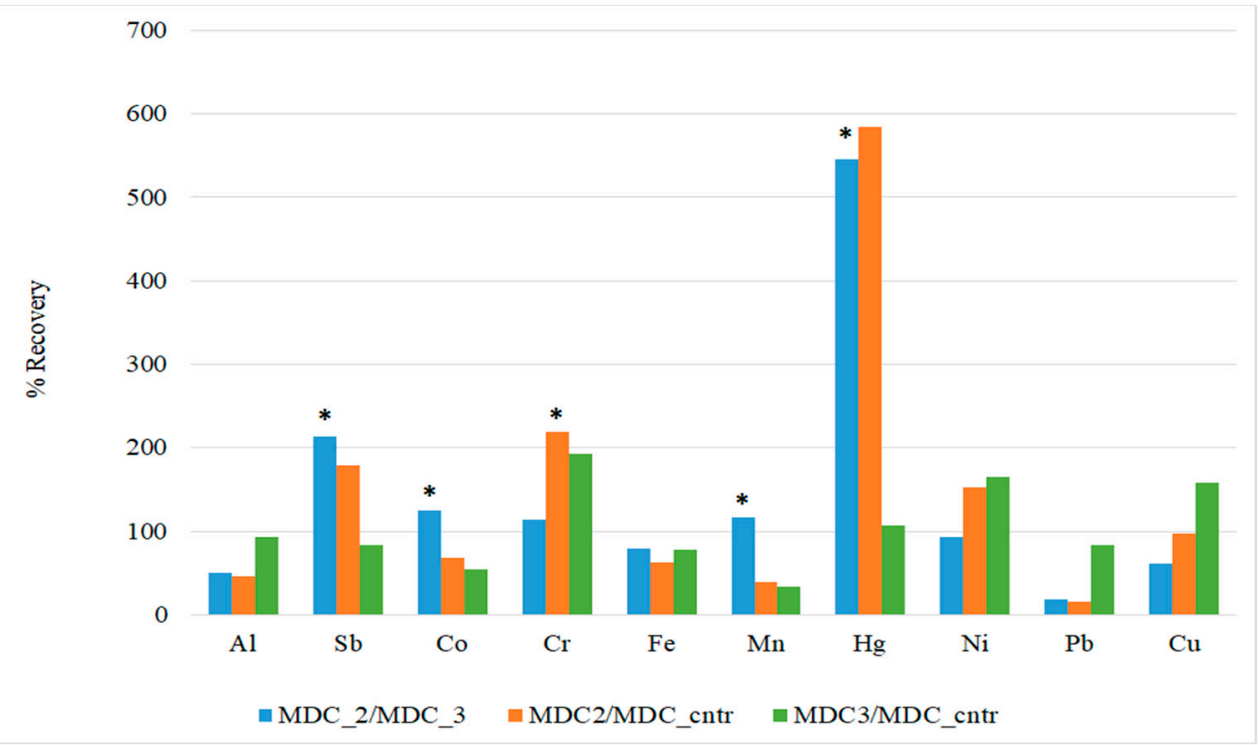

Figure 4. Percentage of metal recovery from MDC_2 membranes in comparison to MDC_3 (MDC_2/MDC_3) and MDC_CNTR (MDC_2/MDC_CNTR). MDC_3/MDC_CNTR: percentage of the metal recovery in MDC_3 in comparison with MDC_CNTR. The asterisks are placed over the histograms of metals, whose recovery was higher in MDC_2.

In Figure 5 as an example, we provide an overview of potential recovered metals from brine MDC_3 system treatment compared to current metal price $[\$ / \mathrm{kg}]$ listed by the U.S. Geological Survey 2021 [35]. Considering the large amounts of brine treated by a scaled-up desalination plant, the amount of metals recovered may translate into a large economic value. Of course, economic advantages are different for the different MDCs' systems. It is also worth noting that potential economic advantages should be evaluated also considering the effective cost of metal recovery, for which there is currently a lack of data. Therefore, future analysis should be focused also on a comparative assessment between economic advantages, recovered metals, and large-scale investments that are needed for implementing these practices.

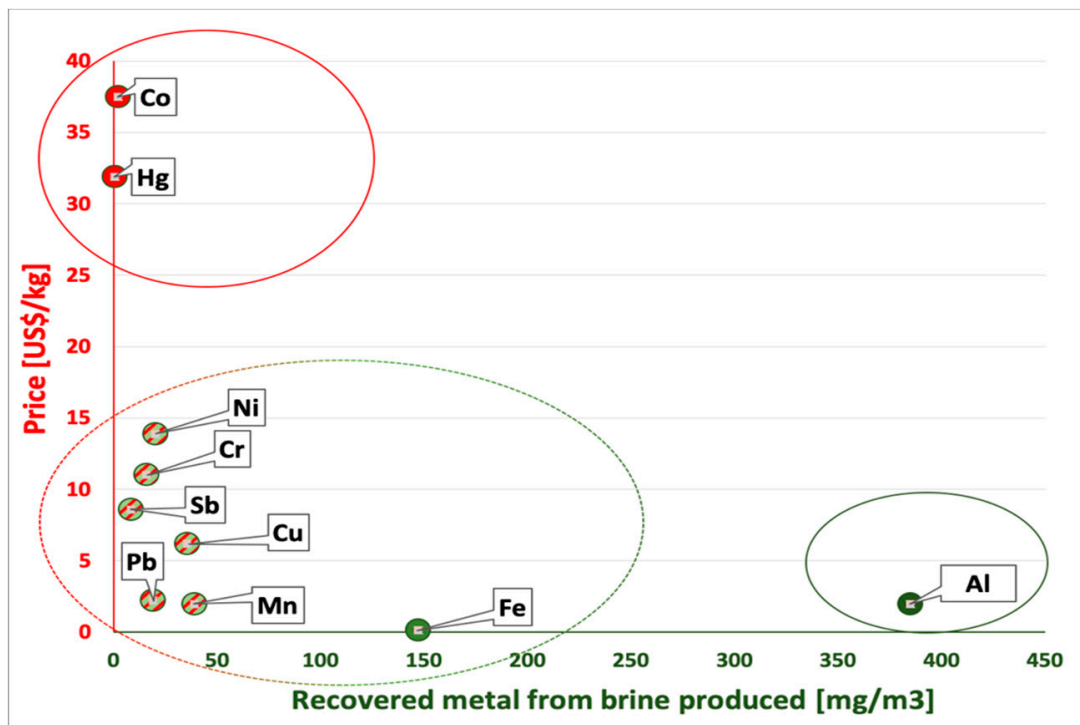

Figure 5. Recovered metals from brine MDC_3 system treatment $\left[\mathrm{mg} / \mathrm{m}^{3}\right]$ versus their market price [\$/kg]. Market prices are based on [35].

Therefore, metal recovery may represent a potential environmental advantage in terms of circular economy $[9,25]$, but the advantages in terms of the avoided release of potential 
toxic chemicals into the water bodies should not be disregarded. Hence, we applied LCA to the investigated processes with the aim of quantifying the avoided life cycle toxic impacts due to metal recovery in terms of avoided human toxicity (HTP) and marine eco-toxicity (ETP) impacts.

Specifically, we can calculate, as an example, the potential avoided impacts because of the recovery of $\mathrm{Al}, \mathrm{Sb}, \mathrm{Co}, \mathrm{Cr}, \mathrm{Fe}, \mathrm{Mn}, \mathrm{Hg}, \mathrm{Ni}, \mathrm{Pb}$, and $\mathrm{Cu}$ for each $\mathrm{m}^{3}$ of brine treated by MDC_2 and, therefore, not released into water bodies. Overall, results—in terms of HTPshow that it would be possible to avoid the release of approximately $3.8 \times 10^{-2} \mathrm{~kg} 1$,4DBeq per $\mathrm{m}^{3}$ of brine produced by desalination plants. Further, the total avoided potential ecotoxicity (ETP) impact due to all the metal recovery would be approximately $6.6 \times 10^{-5} \mathrm{~kg}$ $1,4 \mathrm{DBeq}$ per $\mathrm{m}^{3}$ of brine that is not released into the marine eco-system. Detailed results in terms of avoided life cycle toxic impacts (at mid-point and end-point levels) are provided in Table 3. It should be noted that life cycle toxicity results may include uncertainties due to different exposure, fate, and effect of toxic chemicals. The main environmental advantage arises from the recovery of $\mathrm{Hg}, \mathrm{Cu}$, and $\mathrm{Al}$, although any avoided impact is important, being well known that some chemicals generate impacts also at very low concentrations and that concentrations may increase through the marine metabolic chain.

From an energy perspective, metal recovery may also allow an energy saving because of the use of secondary metal production and, consequently, the avoided life cycle mining activities. Table 4 shows the estimated mining energy values of metals recovered from brine. This estimation is calculated considering the mass of recovered metals from the three MCD systems multiplied by their unit mining energy value, based on Nuss et al., 2014, and Ecoinvent database $[34,36]$. Results show that the main energy savings are associated with the recovery of $\mathrm{Sb}, \mathrm{Cu}$, and $\mathrm{Al}$ per $\mathrm{kg}$ of metals as the CED breakdown for mining activities is, respectively, $117 \mathrm{MJ} / \mathrm{kg}$ (83\% of the total CED), $24 \mathrm{MJ} / \mathrm{kg}$ (45\% of the total CED), and $24 \mathrm{MJ} / \mathrm{kg}$ (18\% of the total CED). It should also be noted that the metal recovery could also represent a combined environmental benefit $[31,37]$, due to finite resource availability of some strategic metals and potential economic gain due to the high cost of some metals such as Co. This last one is commonly used as cathode in battery storage systems as well as in other sectors (as an example, the current price of Co is $\$ 37.48 / \mathrm{kg}$, according to the latest report released by the U.S. Geological Survey).

Being aware that the three MDC systems are able to extract different amounts of each metal, if we compare the cumulative energy demand (Table 4) with the estimated energy required by MDCs to separate and capture the same metals from brine, we can see that MDC_2, MDC_3, and MDC_cntr may require, respectively, a smaller, a higher, and a similar amount of energy compared to the mining practices (Table 5). In particular, MDC_2 only fed by wastewater shows a very promising result for future research. 


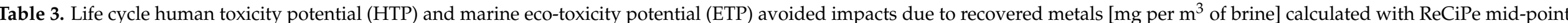

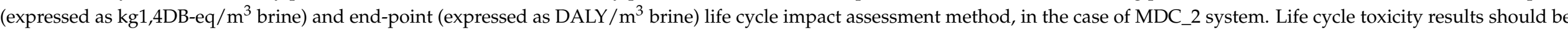

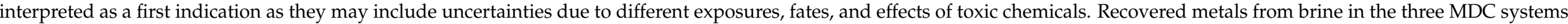
are indicated in Table 4.

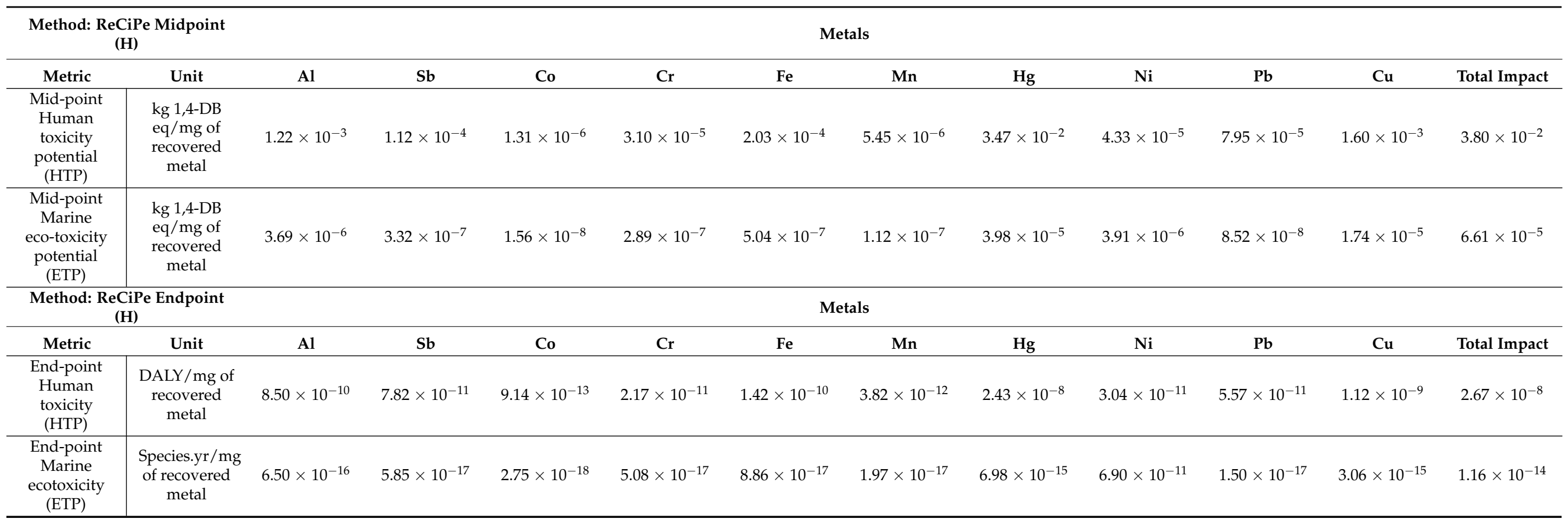


Table 4. Energy values of metals mining vs extraction from brine, based on Nuss et al., 2014 [36].

\begin{tabular}{|c|c|c|c|c|c|c|c|c|c|c|c|}
\hline & Al & $\mathrm{Sb}$ & Co & $\mathrm{Cr}$ & $\mathrm{Fe}$ & Mn & $\mathrm{Hg}$ & $\mathrm{Ni}$ & $\mathrm{Pb}$ & $\mathrm{Cu}$ & $\begin{array}{c}\text { Total } \\
\text { Energy }\end{array}$ \\
\hline $\begin{array}{l}\text { MDC_3 Recovered metals } \\
\left(\mathrm{g} / \mathrm{m}^{3}\right)\end{array}$ & 0.384 & 0.008 & 0.002 & 0.016 & 0.147 & 0.038 & 0.0005 & 0.020 & 0.019 & 0.035 & n.a. \\
\hline $\begin{array}{l}\text { - } \quad \begin{array}{l}\text { MDC_cntr_Recovered metals } \\
\left(\mathrm{g} / \mathrm{m}^{3}\right)\end{array}\end{array}$ & 0.413 & 0.009 & n.a. & 0.003 & 0.008 & 0.188 & 0.113 & 0.0004 & 0.012 & 0.022 & n.a. \\
\hline $\begin{array}{l}\text { - } \quad \text { MDC_2 Recovered metals } \\
\left(\mathrm{g} / \mathrm{m}^{3}\right)\end{array}$ & 0.192 & 0.017 & 0.002 & 0.018 & 0.117 & 0.045 & 0.002 & 0.018 & 0.003 & 0.021 & n.a. \\
\hline - $\quad$ Mining Energy Demand (MJ/g) & 0.024 & 0.117 & n.a. & 0.002 & 0.0002 & 0.012 & n.a. & n.a. & 0.008 & 0.024 & n.a. \\
\hline $\begin{array}{l}\text { - } \quad \text { MDC_3 Extraction Energy } \\
\text { value of metals recovered from } \\
\text { brine }\left(\mathrm{MJ} / \mathrm{m}^{3}\right)\end{array}$ & $9.2 \times 10^{-3}$ & $9.7 \times 10^{-4}$ & n.a. & $3.2 \times 10^{-5}$ & $2.9 \times 10^{-5}$ & $4.7 \times 10^{-4}$ & n.a. & n.a. & $1.5 \times 10^{-4}$ & $8.5 \times 10^{-4}$ & $1.12 \times 10^{-2}$ \\
\hline $\begin{array}{l}\text { MDC_cntr Extraction Energy } \\
\text { value of metals recovered from } \\
\text { brine }\left(\mathrm{MJ} / \mathrm{m}^{3}\right)\end{array}$ & $9.93 \times 10^{-3}$ & $1.16 \times 10^{-3}$ & n.a. & $7.74 \times 10^{-6}$ & $1.66 \times 10^{-6}$ & $2.26 \times 10^{-3}$ & n.a. & n.a. & $9.84 \times 10^{-5}$ & $5.51 \times 10^{-4}$ & $1.40 \times 10^{-2}$ \\
\hline $\begin{array}{l}\text { - } \quad \text { MDC_2 Extraction Energy } \\
\text { value of metals recovered from } \\
\text { brine }\left(\mathrm{MJ} / \mathrm{m}^{3}\right)\end{array}$ & $4.61 \times 10^{-3}$ & $2.07 \times 10^{-3}$ & n.a. & $3.64 \times 10^{-5}$ & $2.35 \times 10^{-5}$ & $5.43 \times 10^{-4}$ & n.a. & n.a. & $2.90 \times 10^{-5}$ & $5.23 \times 10^{-4}$ & $7.84 \times 10^{-3}$ \\
\hline
\end{tabular}


Table 5. Energy provided to the MDCs' systems by either battery and/or wastewater (energy unit/treated brine volume) to separate metals from brine and cumulative energy demand (Nuss et al., 2014). All values are expressed as $\mathrm{MJ} / \mathrm{m}^{3}$ brine.

\begin{tabular}{cccc}
\hline & $\begin{array}{c}\text { Desalination } \\
\text { Process }\end{array}$ & $\begin{array}{c}\text { Mining } \\
\text { Practices }\end{array}$ & $\begin{array}{c}\text { Source of Energy } \\
\text { (Desalination) }\end{array}$ \\
\hline MDC_2 & $3.24 \times 10^{-3}$ & $7.84 \times 10^{-3}$ & Wastewater \\
\hline MDC_3 & $6.18 \times 10^{-1}$ & $1.12 \times 10^{-2}$ & Wastewater + battery \\
\hline MDC_cntr & $1.64 \times 10^{-2}$ & $1.40 \times 10^{-2}$ & Battery \\
\hline
\end{tabular}

Future exploitation of recovered elements will entail the setup of proper and specific processes, at appropriate scale. Nevertheless, the potential advantages associated with the sequestration of metals in MDCs are undoubtedly significant.

\section{Conclusions}

Desalination processes represent a sustainable option for addressing water scarcity and providing fresh water for population and industry purposes. However, a sustainable management of the associated hypersaline brine production should be identified and implemented globally to reduce environmental impacts. Emerging technologies such as MDC technology are potential candidates to address this issue. This work provides a proof of concept focused on the application of MDC technology as potential brine treatment (for stand-alone devices or integrating other desalination processes). Results showed that this approach could provide several benefits, such as energy savings due to reduced metal mining activities, salt removal, resource recovery, wastewater treatment, and reduction of life cycle human and eco-toxicity impacts as well as cumulative energy demand and potential economic advantages due to metal recovery. Although MDCs' process optimization and its scale-up represent a challenge for future industry applications, our analysis provides useful evidence that MDCs' technology can contribute toward a greener pathway of brine treatments from desalination processes.

Author Contributions: E.L. and R.A.N. contributed to the paper outline and paper writing. R.A.N. designed and carried out the experimental activities and collected and elaborated on data. E.L. performed LCA analysis. M.T. (Maria Toscanesi) performed laboratory chemical analyses. M.T. (Marco Trifuoggi) contributed analytic tools. G.L. and S.U. supervised data elaboration, experimental activity, and text editing. All authors have read and agreed to the published version of the manuscript.

Funding: This research was founded by funding for circular economy research from H2020 EU's Marie Skłodowska-Curie ITN program (ReTraCE Project, grant No. 814247), the Italian Ministry of Foreign Affairs and International Cooperation (MAECI, High Relevance Bilateral Projects, Grant No. PGR00954), the Sino-Italian Cooperation of NSFC Natural Science Foundation of China (Grant No. 71861137001), and COGEI S.r.l. (Costruzioni Generali Impiantistiche), Naples, Italy.

Institutional Review Board Statement: Not applicable.

Informed Consent Statement: Not applicable.

Data Availability Statement: Not applicable.

Acknowledgments: A special thanks to Raffaele Cimino, CEO of COGEI, for continuous support and to Paolo Di Giorgio for helping us with some critical calculations.

Conflicts of Interest: The authors declare no conflict of interest.

\section{References}

1. Xevgenos, D.; Moustakas, K.; Malamis, D.; Loizidou, M. An overview on desalination \& sustainability: Renewable energy driven desalination and brine management. Desalination Water Treat. 2016, 57, 2304-2314. [CrossRef]

2. Jones, E.; Qadir, M.; van Vliet, M.T.; Smakhtin, V.; Kang, S.M. The state of desalination and brine production: A global outlook. Sci. Total Environ. 2019, 657, 1343-1356. [CrossRef] 
3. Pistocchi, A.; Bleninger, T.; Dorati, C. Screening the hurdles to sea disposal of desalination brine around the Mediterranean. Desalination 2020, 491, 114570. [CrossRef]

4. Frank, H.; Fussmann, K.E.; Rahav, E.; Zeev, E.B. Chronic effects of brine discharge from large-scale seawater reverse osmosis desalination facilities on benthic bacteria. Water Res. 2019, 151, 478-487. [CrossRef] [PubMed]

5. Giwa, A.; Dufour, V.; Al Marzooqi, F.; Al Kaabi, M.; Hasan, S.W. Brine management methods: Recent innovations and current status. Desalination 2017, 407, 1-23. [CrossRef]

6. Panagopoulos, A.; Haralambous, K.J. Environmental impacts of desalination and brine treatment-Challenges and mitigation measures. Mar. Pollut. Bull. 2020, 161, 111773. [CrossRef]

7. Garrote-Moreno, A.; Fernández-Torquemada, Y.; Sánchez-Lizaso, J.L. Salinity fluctuation of the brine discharge affects growth and survival of the seagrass Cymodocea nodosa. Mar. Pollut. Bull. 2014, 81, 61-68. [CrossRef]

8. Panagopoulos, A.; Haralambous, K.; Loizidou, M. Desalination brine disposal methods and treatment technologies A review. Sci. Total Environ. 2019, 693, 133545. [CrossRef]

9. Morillo, J.; Usero, J.; Rosado, D.; El Bakouri, H.; Riaza, A.; Bernaola, F.J. Comparative study of brine management technologies for desalination plants. Desalination 2014, 336, 32-49. [CrossRef]

10. Almasri, D.; Khaled, A.; Mahmoud, K.A.; Abdel-Wahab, A. Two-stage sulfate removal from reject brine in inland desalination with zero-liquid discharge. Desalination 2015, 362, 52-58. [CrossRef]

11. Tsai, J.H.; Macedonio, F.; Drioli, E.; Giorno, L.; Chou, C.Y.; Hu, F.C.; Li, C.; Chuang, C.J.; Tung, K.L. Membrane-based zero liquid discharge: Myth or reality? J. Taiwan Inst. Chem. E 2017, 80, 192-202. [CrossRef]

12. Jafary, T.; Daud, W.R.W.; Aljlil, S.A.; Ismail, A.F.; Al-Mamun, A.; Baawain, M.S.; Ghasemi, M. Simultaneous organics, sulphate and salt removal in a microbial desalination cell with an insight into microbial communities. Desalination 2018, 445, 204-212. [CrossRef]

13. Al-Mamun, A.; Ahmad, W.; Baawain, M.S.; Khadem, M.; Dhar, B.R. A review of microbial desalination cell technology: Configurations, optimization and applications. J. Clean Prod. 2018, 183, 458-480. [CrossRef]

14. Nastro, R.A. Microbial fuel cells in waste treatment: Recent advances. Int. J. Perform. Eng. 2014, 10, 367-376.

15. Santoro, C.; Arbizzani, C.; Erable, B.; Ieropoulos, I. Microbial fuel cells: From fundamentals to applications. A review. J. Power Sources 2017, 356, 225244. [CrossRef]

16. Gambino, E.; Chandrasekhar, K.; Nastro, R.A. SMFC as a tool for the removal of hydrocarbons and metals in the marine environment: A concise research update. Environ. Sci. Pollut. Res. 2021, 28, 30436-30451. [CrossRef]

17. Falcucci, G.; Nastro, R.A.; Minutillo, M.; De Santis, E.; Erme, G.; Ulgiati, S.; Jannelli, E. Microbial fuel cells fed by solid organic waste: A preliminar experimental study, EFC 2013. In Proceedings of the 5th European Fuel Cell Piero Lunghi Conference 2013, 139-140 5th European Fuel Cell Piero Lunghi Conference and Exhibition, EFC 2013, Rome, Italy, 11-13 December 2013. Code 110891.

18. Florio, C.; Nastro, R.A.; Flagiello, F.; Minutillo, M.; Pirozzi, D.; Pasquale, V.; Ausiello, A.; Toscano, G.; Jannelli, E.; Dumontet, S. Biohydrogen production from Solid Phase-Microbial Fuel Cell spent substrate: A preliminary study. J. Clean Prod. 2019, 227, 506-511. [CrossRef]

19. Endreny, T.; Avignone-Rossa, C.; Nastro, R.A. Generating electricity with urban green infrastructure microbial fuel cells. J. Clean Prod. 2020, 263, 121337. [CrossRef]

20. Jegathambal, P.; Nisha, R.R.; Parameswari, K.; Subathra, M.S.P. Desalination and removal off organic pollutants using electrobiochemical reactor. Appl. Water Sci. 2019, 9, 113. [CrossRef]

21. Santoro, C.; Abad, F.B.; Serov, A.; Kodali, M.; Howe, K.J.; Soavi, F.; Atanassov, P. Supercapacitive microbial desalination cells: New class of power generating devices for reduction of salinity content. Appl. Energy 2017, 208, 25-36. [CrossRef]

22. Rahman, S.; Jafary, T.; Al-Mamun, A.; Baawain, M.S.; Choudhury, M.R.; Alhaimali, H.; Siddiqi, S.A.; Dhar, B.R.; Sana, A.; Lam, S.S.; et al. Towards upscaling microbial desalination cell technology: A comprehensive review on current challenges and future prospects. J. Clean Prod. 2021, 288, 125597. [CrossRef]

23. Carmalin, S.A.; Bhalambaal, V.M.; Lima, E.C.; Thirunavoukkarasu, M. Microbial desalination cell technology: Contribution to sustainable wastewater treatment process, current status and future applications. J. Environ. Chem. Eng. 2016, 4, 3468-3478. [CrossRef]

24. Malakootian, M.; Mahdizadeh, H.; Nasiri, A.; Mirzaienia, F.; Hajhoseini, M.; Amirmahani, N. Investigation of the efficiency of microbial desalination cell in removal of arsenic from aqueous solutions. Desalination 2018, 438, 19-23. [CrossRef]

25. Forrestal, C.; Xu, P.; Ren, Z. Sustainable desalination using a microbial capacitive desalination cell. Energy Environ. Sci. 2012, 5, 7161. [CrossRef]

26. Logan, B.; Cheng, S.; Watson, V.; Estadt, G. Graphite Fiber Brush Anodes for Increased Power Production in Air-Cathode Microbial Fuel Cells. Environ. Sci. Technol. 2007, 41, 3341-3346. [CrossRef]

27. Guinée, J.B.; Lindeijer, E. Handbook on Life Cycle Assessment: Operational Guide to the ISO Standards; Springer Science \& Business Media: Berlin/Heidelberg, Germany, 2002.

28. Consoli, F.; Allen, D.; Boustead, I.; de Oude, N.; Fava, J.; Franklin, R.; Jensen, A.A.; Parrish, R.; Perriman, R.; Postlethwaite, D.; et al. Guidelines for Life-Cycle Assessment: A “Code of Practice". In Proceedings of the SETAC Workshop, Sesimbra, Portugal, 31 March-3April 1993. 
29. International Organization for Standardization, Standard ISO, 14040 Environmental Management-Life Cycle AssessmentPrinciples and Framework. 2006. Available online: https://www.iso.org/standard/37456.html (accessed on 15 April 2021).

30. International Organization for Standardization, Standard ISO, 14044 Environmental Management-Life Cycle AssessmentRequirements and Guidelines. Available online: https://www.iso.org/standard/38498.html (accessed on 15 April 2021).

31. Corcelli, F.; Ripa, M.; Leccisi, E.; Cigolotti, V.; Fiandra, V.; Graditi, G.; Sannino, L.; Tammaro, M.; Ulgiati, S. Sustainable urban electricity supply chain-Indicators of material recovery and energy savings from crystalline silicon photovoltaic panels end-of-life. Ecol. Indic. 2018, 94, 37-51. [CrossRef]

32. Buonocore, E.; Mellino, S.; De Angelis, G.; Liu, G.; Ulgiati, S. Life cycle assessment indicators of urban wastewater and sewage sludge treatment. Ecol. Indic. 2018, 94, 13-23. [CrossRef]

33. Goedkoop, M.; Heijungs, R.; Huijbregts, M.; De Schryver, A.; Struijs, J.; Van Zelm, R. ReCiPe 2008. In A Life Cycle Impact Assessment Method Which Comprises Harmonized Category Indicators at the Midpoint and the Endpoint Level, 1st ed.; Version 1.08; Ministry of Housing Spatial Planning and the Environment: The Hague, The Netherlands, 2009; Volume 6, pp. 1-26.

34. The Ecoinvent Database. Available online: https://www.ecoinvent.org/references/references.html (accessed on 15 April 2021).

35. U.S. Geological Survey. Mineral Commodity Summaries 2020: U.S. Geological Survey; U.S. Geological Survey: Reston, VA, USA, 2020; ISBN 978-1-4113-4362-7. [CrossRef]

36. Nuss, P.; Eckelman, M.J. Life cycle assessment of metals: A scientific synthesis. PLoS ONE 2014, 9, e101298. [CrossRef]

37. Loganathan, P.; Naidu, G.; Vigneswaran, S. Mining valuable minerals from seawater: A critical review. Environ. Sci. Water Res. Technol. 2017, 3, 37-53. [CrossRef] 